\title{
THE LEVEL OF IMPORTANCE ATTACHED TO PRICE AND QUALITY IN PURCHASING BEHAVIOUR
}

\author{
S BRIJBALL \\ School of Human Resource Management \\ Faculty of Law, Economics and Management \\ University of Durban-Westville
}

\begin{abstract}
The study evaluates the level of importance consumers attach to specific product attributes and the perceived relationship between price and quality. An empirical analysis is undertaken on a sample of 237 Indian consumers drawn using the stratified random sampling technique. The results indicate that quality followed by price are important general evaluative criteria but their importance diminishes when other product attributes are included. Furthermore, only a quarter of the subjects perceive price and quality as having a one to one relationship. Also, biographical profiles do not impact on the level of importance attached to price but age and income influence the importance attached to quality.
\end{abstract}

\section{OPSOMMING}

Hierdie studie evalueer die belangrikheidsvlak wat verbruikers aan spesifieke produk- kenmerke en die waargenome verhouding tussen prys en kwaliteit heg. Die empiriese ontleding is op 237 Indiër-verbruikers uitgevoer en daar is gebruik gemaak van 'n gestratifiseerde steekproefnemingstegniek. Die bevindinge van die studie dui daarop dat kwaliteite en prys twee belangrike produkkenmerke is, maar hulle belangrikheid verminder sodra ander produkkenmerke ingesluit word. Net 'n kwart van die verbruikers glo dat prys en kwaliteit ' $n$ een tot een verhouding het. Die studie dui daarop dat die biografiese profiele van verbruikers nie op die belangrikheidsvlak van prys impakteer nie, maar dat ouderdom en inkomste die belangrikheidsvlak wat aan kwaliteit gekoppel word, beïnvloed.

Improved communication networks, human being's desire to progress and live better lifestyles, effective marketing strategies (promotions and advertising) and the free market system have undoubtedly enlarged man's sphere of needs. However, individuals' disposable incomes do not increase at the same rate as their demand for goods and services. Hence, the consumer can no longer always engage in the simple purchasing of products but is forced to weigh up the pros and cons of available alternatives in order to obtain maximum utility from scarce resources. Therefore the evaluation, purchase and use of economic goods and services involve the accumulation of complex mental and physical activities.

The consumer decision-making process signifies goal-striving behaviour and is not just a single activity. It is a sequential and repetitive series of psychological and physical activities ranging from problem recognition to post-purchase behaviour. However, consumers do not function in isolation. They are influenced by numerous individual factors such as needs, motives, personality, perception, learning and attitudes. Consumers are also influenced by environmental factors such as culture, social, business and market influences, reference groups, family and economic demand factors. All of these can collectively be referred to as the 'psychological field'. These variables constantly and simultaneously interact and play a leading role in the final outcome of the consumer's choice.

In any purchasing situation, individuals absorb information from their external environment and integrate it with their inner needs, motives, perceptions and attitudes. The chosen outcome may be influenced by past experiences, the act of recalling and personality factors. A person is also influenced profoundly by his/her environment. The consumer often encounters family, cultural and reference group influences, peer group pressure, economic demands and persuasive advertising. However, despite these influences and marketing pressures, the decision whether or not to buy in the final purchase situation is an individual one (du Plessis, Rousseau

Requests for copies should be addressed to: $S$ Brijball, Department of Human Resource Management, Faculty of Law, Economics and Managemenr, University of Durban-Westville, Private Bag X54001, Durban, 4000 and Blem, 1990). By analysing the internal thought processes of consumers as they undergo the process of decision making, marketers can determine the criteria that consumers use when engaging in purchase decisions, the importance thereof and the dominant influencing variables. The final choice is also the outcome of perceptions of price and quality.

\section{Price}

Price measures what must be 'foregone/given up' in a transaction in order to receive the desired benefits. There exist substantial inconclusive results with regards to consumers' subjective perceptions of price. However, a study undertaken by Petroshius and Monroe (1987) suggests that price is used by individuals as an informational stimulus for judging the product. In a product line context, when the buyer is confronted with a line of products and their prices, the price characteristics of the product line influences consumer evaluations (Petroshius and Monroe, 1987).

\section{Quality}

Consumers often judge the quality of a product on the basis of a variety of informational cues that they associate with the product. Some of these cues are specific product characteristics (for example, colour) and are therefore, intrinsic cues. Some cues are extrinsic to the product, for example, price, store image, and brand image. Extrinsic cues are attributes which are 'product related' but are not a part of the physical product (Wheatley, Chiu and Goldman, 1981). Either individually or integrated, these intrinsic and extrinsic cues form the foundation for perceptions of product quality.

\section{Perceived price-quality relationship}

Price is not only representative of product cost but is an extrinsic or external cue that helps the consumers to judge the quality of products or brands and to determine the anticipated level of satisfaction. Buyers may choose to rely on extrinsic attributes, such as price, as a summary measure of product quality level in order to escape information overload or to help make an assessment (Martins and Monroe, 1994). Since consumers want to get their money's worth, they believe that they get what is paid 
for. Hence the perception: the higher the price, the better the quality. Venkataraman (1981) indicates a positive relationship between price and perceptions of product quality with regards to some price ranges and for certain product categories. Schiffman and Kanuk (1991) report that consumers attribute varying qualities to identical products that carry different price labels. Furthermore, because price is often considered to be a determinant of quality, some products deliberately justify a high price by their claims of signifying quality. Conversely, the perceived quality inference can sometimes lead to unexpected results. A store's prices can be perceived as being 'too low' and consumer demand for a product may actually decline if it is perceived as lacking in desired quality (Wilkie, 1990).

The price-quality relationship is often used by real estate developers in positioning their offering as well as in the realm of consumer services (Zeithaml, 1988). However, Zeithaml (1988) emphasizes that the extent of positive price-quality perceptions varies across service categories. Furthermore, Peter and Olson (1996) reported that the perceived price-quality relationship is typical when consumers are given no further information about the product except price. However, when additional information about products are presented to consumers, the price-quality relationship declines.

Consumers generally rely more on price as a reflection of quality when they see the purchase as being risky, when they have low self-confidence and lack product experience and when there are no criteria for judging the performance of the product. Conversely, when the consumer is familiar with a brand name or has experience with a product, price declines as a determinant in product selection. Furthermore, consumers associate higher price with higher quality when they feel that there are ample quality differences between the brands or they perceive quality variations in a product category (Assael, 1987). According to Obermiller (1988), the product line structure, the existence of multiple quality levels under one brand name, is found to be a predictor of price-quality effects. Hence, consumers who use price as a surrogate indicator of quality do so because they believe differences in quality exist. Justifiably then, these consumers display a greater preference for higher-priced brands and products than individuals who do not believe that quality varies among brands and products.

Zeithaml (1988) reported that price is used as a quality cue to a greater extent when brands are unfamiliar than when they are familiar. When consumers purchase new or unfamiliar products, they perceive social, economic and psychological risks. The consumer is prepared to pay a little more to reduce perceived risks. Zeithaml (1988) deduced that when perceived risk of making an unsatisfactory choice is high, consumers select higher priced products.

Whilst it is common to judge quality by price, the rational consumer would not pay extra for a product unless it had the potential of delivering greater satisfaction. Most individuals have a ceiling and floor limit on the prices they are willing to pay. Consumers tend to shop for products whose prices fall within the absolute price thresholds. Price perception also depends on consumers' differential thresholds since the change in price has to be greater than a specific amount in order to be noticed by the consumers. Brassington and Pettitt (1997) reflected that the higher the quality and the prestige image of the product, the lower the price sensitivity. Furthermore, the price perceptions of consumers depend on the differences between the actual price and the price they use as a basis for comparison. In the cognitive processing of price information, consumers may make use of this internal reference price (Peter and Olson, 1996). Consumers may develop "a set of standard prices for different product categories and quality levels that serve as a frame of reference", when evaluating the price of a specific product (Engel, Blackwell and Miniard, 1986, p. 305).
It is evident that consumers can use price as a means of comparing products, judging relative value for money or judging product quality (Brassington and Pettitt, 1997). Hence, the perceived price-quality inference is active in the consumer marketplace. But there exists substantial inconclusive results with regards to consumers' subjective perceptions of price. Empirical research on the perceived price-quality relationship could be labeled as being haphazard with little accumulation of results, leading Peterson and Wilson (1985) to conclude that the perceived price-quality relationship is neither particularly general nor robust. Peter and Olson (1996) reiterated these views by stating that research on the behavioural effects of pricing has not been based on sound theory and that most of the studies are seriously flawed methodologically thereby, reaching little consensus on basic issues of how price affects consumer choice processes and behaviour.

\section{Focus/objectives of the study}

This study aims to firstly, investigate the importance that consumers from various biographical profiles attach to the evaluative criteria of price and quality when engaging in consumer decision-making and choice selection. Secondly, the study aims to investigate whether consumers from different biographical profiles perceive price and quality as having a one to one relationship. Stated differently, the objective is to deduce whether a one to one relationship exists between actual price and actual product quality, that is, is price an accurate determinant of quality? Or does a proportionate increase/decrease in price suggest an equivalent increase/decrease in quality?

\section{Hypotheses}

Hypothesis 1

There are statistically significant differences in the mean scores of groups formed on the basis of various biographical variables (such as socio-economic status, gender, marital status, education, age and income) in respect of the importance attached to the price of grocery products.

\section{Hypothesis 2}

There are statistically significant differences in the mean scores of groups formed on the basis of various biographical variables (such as socio-economic status, gender, marital status, education, age and income) in respect of the importance attached to the quality of grocery products.

\section{METHOD}

\section{Respondents}

A sample of 237 subjects was drawn from the Chatsworth area using the stratified random sampling method. This district was selected since it is the largest region originally designated for Indians and it is representative of the various socio-economic classes in the Indian community. Indians were selected for the study since they are typically regarded as "trolley buyers" and hence, it would be strategic from a marketing perspective, to study the purchasing patterns of these consumers. The sample comprises of all those individuals who engage in household shopping. The strata were geographically determined. The Chatsworth area was divided into 16 strata on the basis of designated units in the Chatsworth directory. Random sampling followed, based on street names and then, actual house addresses were drawn. The biographical profiles were based on socio-economic status, gender, marital status, education, age and income. The initial sample size was 240 However, as a result of 3 incomplete questionnaires, the sample was reduced to 237. The adequacy of the sample was determined on the basis of the Kaiser-Olkin Measure of Sampling Adequacy (0.83051) and the Bartlet Test of Sphericity (20 023.015) which respectively showed suitability and significance. 


\section{Measuring instrument}

The measuring instrument was a self-developed, precoded, standardised questionnaire comprising of Section A (Biographical data) and Section B (perceptions of evaluative criteria and price-quality relationships when purchasing grocery products). Section A was nominally scaled with preestablished option categories. Items in Section B were measured using the 1 to 5 point rating scale and choice categories. Subjects were required to rate the level of importance they attach to the various evaluative criteria, namely, price, quality, brand name, label information, choice/variety, nutritional value, appearance, freshness, taste, shelf life on a 1 to 5 point rating scale, ranging from least important (1) to most important (5). The higher the score, the greater the importance that respondents attach to that criterion when engaging in decision-making or choice behaviour. Furthermore, respondents were requested to reflect how they perceive the relationship between price and quality. Subjects were required to select the most appropriate response from three choice categories: 'Price is always a good indicator of quality', 'Price is sometimes a good indicator of quality' and 'Price is never a good indicator of quality'.

\section{Procedure}

The questionnaires were individually and personally administered in each household. This was done to ensure that every household that was drawn from the listing was visited and to ensure that subjects, some of whom were illiterate and semi-literate, understood the questions and the scaling. Wherever necessary, explanations were given regarding the scaling and the researcher was cautious when documenting the responses (especially of illiterate respondents) and ensured that procedures followed were as standardised as possible. All literate subjects completed the questionnaire themselves, although clarification was possible due to the presence of the researcher. In the event of absence of household inhabitants, one further visit was made and then (according to preestablished procedures) the inhabitants in the house on the right, and lastly, the house on the left, were approached. The same procedure was adopted when subjects chose not to participate, although the latter was the response of only 7 households drawn.

\section{Statistical Analysis \\ Reliability}

The internal consistency of the questionnaire or the degree of homogeneity among the items was assessed using Cronbach's Coefficient Alpha. The obtained Coefficient Alpha of 0.8670 indicates that the questionnaire is highly reliable and can consistently measure the level of importance of the various evaluative criteria, and the perceived price-quality relationship of consumers.

\section{Descriptive and inferential statistics}

Descriptive statistics using frequency analyses, percentages and mean analyses were undertaken to evaluate the level of importance attached to the evaluative criteria used when engaging in decision-making. Frequencies and percentages were utilised to evaluate price-quality perceptions of consumers. Inferential statistics were also computed to generate the findings. The Kruskal-Wallis One Way Analysis of Variance and the Mann-Whitney U Test were used to assess the impact of biographical profiles on the level of importance attached to price and quality when engaging in choice behaviour.

\section{RESULTS}

The importance of price and quality in consumer decision-making

Consumers were requested to indicate the level of importance they attached to various evaluative criteria (price, quality, brand name, label information, choice/variety, nutritional value, appearance, freshness, taste, shelf life) when engaging in the purchase of grocery products. Subjects responded on a 1 to 5 point scale ranging from least important (1) to most important (5). Although the paper focused on the evaluative criteria of price and quality, other attributes were included since the importance of price and quality are likely to be different when other product information are included. The product attributes were categorised into general criteria (price, quality, brand name, label information, choice/variety) and food product's criteria (nutritional value, appearance, freshness, taste, shelf life). The level of importance of the 10 product criteria is reflected in Table 1.

TABLE 1

LEVEL F IMPORTANCE OF PRODUCT ATTRIBUTES (FREQUENCY AND PERCENTAGE)

\begin{tabular}{|c|c|c|c|c|c|c|}
\hline \multirow{2}{*}{$\begin{array}{l}\text { Product } \\
\text { Attributes }\end{array}$} & \multicolumn{6}{|c|}{ Level of Importance } \\
\hline & & \\
\hline & 1 & 2 & 3 & 4 & 5 & TOTAI \\
\hline \multirow[t]{2}{*}{ Price } & 14 & 3 & 29 & 37 & 154 & 237 \\
\hline & 5.9 & 1.3 & 12.2 & 15.6 & 65.0 & 100 \\
\hline \multirow[t]{2}{*}{ Quality } & 2 & 2 & 11 & 38 & 184 & 237 \\
\hline & 0.8 & 0.8 & 4.6 & 16.0 & 77.6 & 100 \\
\hline \multirow[t]{2}{*}{ Brand Name } & 28 & 24 & 67 & 49 & 69 & 237 \\
\hline & 11.8 & 10.1 & 28.3 & 20.7 & 29.1 & 100 \\
\hline \multirow[t]{2}{*}{ Label information } & 11 & 22 & 52 & 60 & 92 & 237 \\
\hline & 4.6 & 9.3 & 21.9 & 25.3 & 38.8 & 100 \\
\hline \multirow[t]{2}{*}{ Choice/variety } & 8 & 22 & 56 & 60 & 91 & 237 \\
\hline & 3.4 & 9.3 & 23.6 & 25.3 & 38.4 & 100 \\
\hline \multicolumn{7}{|c|}{ Food Product Attributes } \\
\hline \multirow[t]{2}{*}{ Nutritional Value } & 2 & 3 & 6 & 34 & 192 & 237 \\
\hline & 0.8 & 1.3 & 2.5 & 14.3 & 81.0 & 100 \\
\hline \multirow[t]{2}{*}{ Appearance } & 15 & 17 & 62 & 55 & 88 & 237 \\
\hline & 6.3 & 7.2 & 26.2 & 23.2 & 37.1 & 100 \\
\hline \multirow[t]{2}{*}{ Freshness } & 2 & 0 & 3 & 9 & 223 & 237 \\
\hline & 0.8 & 0 & 1.3 & 3.8 & 94.1 & 100 \\
\hline \multirow[t]{2}{*}{ Taste } & 2 & 0 & 28 & 33 & 174 & 237 \\
\hline & 0.8 & 0 & 11.8 & 13.9 & 73.4 & 100 \\
\hline \multirow[t]{2}{*}{ Shelf life } & 2 & 7 & 8 & 37 & 183 & 237 \\
\hline & 0.8 & 3.0 & 3.4 & 15.6 & 77.2 & 100 \\
\hline
\end{tabular}

Table 1 reflects that:-

- The majority of the subjects assigned a rating of 5 to freshness, nutritional value, quality, shelf life, taste and price respectively in descending order of importance. The implication is that when engaging in the purchases of grocery products, consumers take special cognisance of these attributes in product evaluation, although to varying degrees.

- The criteria considered 'most important' in descending order of level of importance for products in general are as follows: Quality (77.6\%), Price (65.0\%), Label information (38.8\%), Choice/variety (38.4\%), Brand name (29.1\%).

- Evidently, quality surfaces as being the most important criterion amongst the general criteria. This outcome can be attributed to the fact that consumers search for 'good value for money'. Price follows quality in level of importance. This can be explained by the fact that man has unlimited wants and limited resources and thus, has 
to economise in order to obtain a 'fuller trolley' within the budget constraint. Furthermore, considering the high rate of inflation and the consequent, difficult economic circumstances, consumers are forced to be price conscious.

- The criteria considered 'most important' in descending order of level of importance for food products are as follows: Freshness (94.1\%), Nutritional Value (81.0\%), Shelf Life (77.2\%), Taste (73.4\%), Appearance (37.1\%).

- When combining general and food product attributes, the criteria considered 'most important' in descending order of level of importance are as follows: Freshness (94.1\%), Nutritional Value (81.0\%), Quality (77.6\%), Shelf Life (77.2\%), Taste $(73.4 \%)$, Price $(65.0 \%)$, Label Information (38.8\%), Choice/variety (38.4\%), Appearance (37.1\%), Brand Name (29.1\%).

The analysis clearly reveals that whilst quality followed by price surfaced as the two main general evaluative criteria, their importance diminished when other product attributes were included.

Mean analyses were undertaken to obtain a holistic indication of the importance of these evaluative criteria. The aim was to obtain average weightings on these criteria rather than to rely on just the number of subjects who rated each criterion as 5 , that is, as being most important (Table 2).

TABLE 2

MEAN LEVEL OF IMPORTANCE OF EVALUATIVE CRITERIA: THE PURCHASE OF GROCERY PRODUCTS

\begin{tabular}{ll}
\hline Evaluative Criteria & Mean \\
\hline Price & 4.351 \\
Quality & 4.691 \\
Brand Name & 3.505 \\
Label Information & 3.845 \\
Choice/variety & 4.103 \\
Nutritional Value & 4.753 \\
Appearance & 3.825 \\
Freshness & 4.928 \\
Taste & 4.577 \\
Shelf Life & 4.701 \\
\hline
\end{tabular}

It is evident from Table 2 that:-

- The mean analyses alter the order of importance of the evaluative criteria and specifically reposition quality behind shelf life and label information behind choice/variety placing them in lesser degrees of importance.

- The criteria, based on mean analyses, in descending level of importance are: Freshness, Nutritional Value, Shelf Life, Quality, Taste, Price, Choice/variety, Label information, Appearance, Brand Name.

When further product information is given and food products are included the prioritised evaluative criterion is freshness followed by nutritional value, shelf life and then quality. These priorities are shown in Figure 1. The findings are congruent with consumers becoming more and more health and fitness conscious. Price also diminishes in importance when other product evaluative criteria are included, moving from second position to sixth.

Impact of biographical variables on consumer ratings of the importance of price and quality

An investigation was undertaken to determine whether the ratings of importance of the evaluative criteria of price and quality are influenced by biographical profiles (Table 3 ).

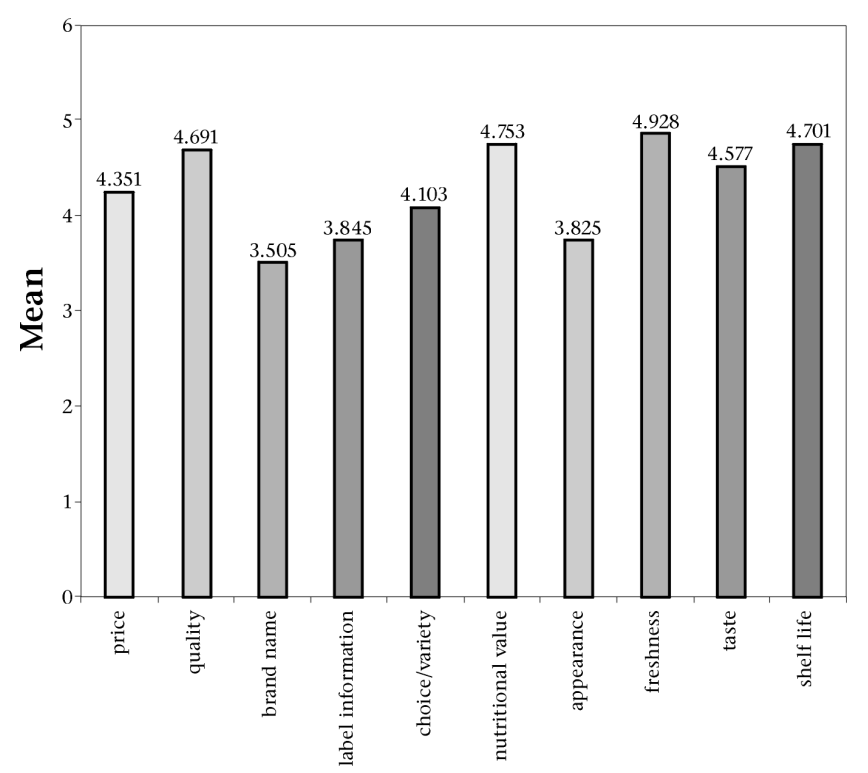

Evaluative Criteria

Figure 1: Mean level of importance of evaluative criteria

TABLE 3

MEAN LEVEL OF IMPORTANCE OF PRICE AND QUALITY

\begin{tabular}{|c|c|c|c|c|c|c|}
\hline \multicolumn{7}{|c|}{$\begin{array}{l}\text { Kruskal-Wallis One-Way Analysis of Variance: } \\
\text { Mean Level of Importance of Price and Quality }\end{array}$} \\
\hline \multirow[t]{2}{*}{ Biographical Variable } & \multicolumn{6}{|c|}{ Price Quality } \\
\hline & Mean & $\mathrm{H}$ & $\mathrm{p}$ & Mean & $\mathrm{H}$ & $\mathrm{p}$ \\
\hline Socio-economic status & 4.351 & 0.095 & 0.954 & 4.691 & 3.498 & 0.174 \\
\hline Marital Status & 4.351 & 0.708 & 0.702 & 4.691 & 3.973 & 0.137 \\
\hline Education & 4.351 & 4.260 & 0.372 & 4.691 & 5.172 & 0.270 \\
\hline Age & 4.351 & 6.067 & 0.300 & 4.691 & 11.308 & $0.046^{*}$ \\
\hline Income & 4.351 & 3.865 & 0.425 & 4.691 & 10.850 & $0.028 *$ \\
\hline \multicolumn{7}{|c|}{ Mann-Whitney U Test: Mean Level of Importance of Price and Quality } \\
\hline & Mean & $\mathrm{H}$ & $\mathrm{p}$ & Mean & $\mathrm{H}$ & $\mathrm{p}$ \\
\hline Gender & 4.351 & 6048.0 & 0.215 & 4.691 & 6862.50 & 0.457 \\
\hline
\end{tabular}

Table 3 indicates that there is no significant difference in the level of importance given to price as an evaluative criterion by consumers varying in biographical profiles (socio-economic status, gender, marital status, education, age, income) when engaging in the purchase of grocery products respectively, at the $5 \%$ level of significance. Hence, hypothesis 1 may be rejected. Similarly, the level of importance attached to the quality of the product is not influenced by socio-economic status, gender, marital status, and education. However, there is a significant difference in the level of importance attached to quality by consumers varying in age and income respectively, at the $5 \%$ level of significance. Hence, hypothesis 2 may be only partially accepted.

The perceived price-quality relationship by consumers An evaluation was undertaken to determine the extent to which consumers regard the price of grocery products as a good indicator of the quality of the product (Table 4). 
TABLE 4

Price-Quality Perception OF CONSUMERS For GRoCery PRODUCTS

\begin{tabular}{lllll}
\hline \multicolumn{5}{c}{ Price as an indicator of Quality } \\
\hline & Always & Sometimes & Never & TOTAL \\
\hline $\mathrm{N}$ & 59 & 122 & 56 & 237 \\
$\%$ & 24.89 & 51.48 & 23.63 & 100 \\
\hline
\end{tabular}

From Table 4, three important conclusions emerge:-

- More than half of the total sample (51.48\%) indicated that the price of the grocery product is sometimes a good indicator of its quality.

- If we combine the sometimes (51.48\%) and the always (24.89\%) categories, it can be maintained that the majority of the subjects (76.37\%) are more likely to base their judgement of quality on the criterion of price.

- The $24.89 \%$ of the subjects that feel that price is always a good indicator of quality, are of the opinion that more expensive products are of a better quality and cheaper products are inferior in quality. These consumers perceive a 1:1 relationship between price and quality.

- Almost a quarter of the subjects (23.63\%) think that price is never a good indicator of quality.

Perceived price-quality relationship by consumers: Impact of biographical variables

A descriptive analysis was undertaken to evaluate the pricequality perception of consumers in terms of each biographical variable (socio-economic status, gender, marital status, education, age, income) (Table 5).

TABLE 5

\section{Price-quality Perception of CONSUMers} (FREQUENCY AND PERCENTAGE)

\begin{tabular}{|c|c|c|c|c|c|c|c|c|}
\hline $\begin{array}{l}\text { Biographical } \\
\text { Variable } \\
\text { Socio-econom }\end{array}$ & Pri & $\begin{array}{l}\text { e as an i } \\
\text { lways }\end{array}$ & $\begin{array}{r}\text { dicate } \\
\text { Son }\end{array}$ & $\begin{array}{l}\text { of Qua } \\
\text { etimes }\end{array}$ & & ver & \multicolumn{2}{|c|}{ TOTAL } \\
\hline \multicolumn{9}{|l|}{ Status } \\
\hline Lower & 17 & 7.17 & 38 & 16.03 & 20 & 8.44 & 75 & 31.65 \\
\hline Middle & 17 & 7.17 & 45 & 18.99 & 13 & 5.49 & 75 & 31.65 \\
\hline Upper & 25 & 10.55 & 39 & 16.46 & 23 & 9.70 & 87 & 36.71 \\
\hline TOTAL & 59 & 24.89 & 122 & 51.48 & 56 & 23.63 & 237 & 100 \\
\hline
\end{tabular}

Gender

\begin{tabular}{lrrrrrrrr}
\hline Males & 24 & 10.13 & 47 & $\mathbf{1 9 . 8 3}$ & 18 & 7.59 & 89 & 37.55 \\
Females & 35 & 14.77 & 75 & 31.65 & 38 & 16.03 & 148 & 62.45 \\
TOTAL & 59 & 24.89 & 122 & 51.48 & 56 & 23.63 & 237 & 100 \\
\hline
\end{tabular}

Marital Status

\begin{tabular}{lrrrrrrrr}
\hline Single & 11 & 4.64 & 29 & 12.24 & 6 & 2.53 & 46 & 19.41 \\
Married & 46 & 19.41 & 86 & 36.29 & 45 & 18.99 & 177 & 74.68 \\
Divorced & 2 & 0.84 & 7 & 2.95 & 5 & 2.11 & 14 & 5.91 \\
TOTAL & 59 & 24.89 & 122 & 51.48 & 56 & 23.63 & 237 & 100 \\
\hline
\end{tabular}

\section{Education}

\begin{tabular}{lrrrrrrrr}
\hline Below Std. 3 & 2 & 0.84 & 2 & 0.84 & 0 & 0 & 4 & 1.69 \\
Stds 3 to 5 & 6 & 2.53 & 10 & 4.22 & 5 & 2.11 & 21 & 8.86 \\
Stds 6 to 9 & 14 & 5.91 & 30 & 12.66 & 13 & 5.49 & 57 & 24.05 \\
Standard 10 & 13 & 5.49 & 28 & 11.81 & 21 & 8.86 & 62 & 26.16 \\
Post-matric & 24 & 10.13 & 52 & 21.94 & 17 & 7.17 & 93 & 39.24 \\
TOTAL & 59 & 24.89 & 122 & 51.48 & 56 & 23.63 & 237 & 100
\end{tabular}

\begin{tabular}{|c|c|c|c|c|c|c|c|c|}
\hline \multicolumn{9}{|l|}{ Age } \\
\hline Under 20 & 2 & 0.84 & 7 & 2.95 & 1 & 0.42 & 10 & 4.22 \\
\hline $20-29$ & 13 & 5.49 & 28 & 11.81 & 11 & 4.64 & 52 & 21.94 \\
\hline $30-39$ & 20 & 8.44 & 40 & 16.88 & 20 & 8.44 & 80 & 33.76 \\
\hline $40-49$ & 17 & 7.17 & 29 & 12.24 & 14 & 5.91 & 60 & 25.32 \\
\hline $50-59$ & 6 & 2.53 & 16 & 6.75 & 8 & 3.38 & 30 & 12.66 \\
\hline 60 and over & 1 & 0.42 & 2 & 0.84 & 2 & 0.84 & 5 & 2.11 \\
\hline TOTAL & 59 & 24.89 & 122 & 51.48 & 56 & 23.63 & 237 & 100 \\
\hline
\end{tabular}

Income

\begin{tabular}{lrrrrrrrr}
\hline $0-1499$ & 17 & 7.17 & 31 & 13.08 & 11 & 4.64 & 59 & 24.89 \\
$1500-2499$ & 16 & 6.75 & 35 & 14.77 & 16 & 6.75 & 67 & 28.27 \\
$2500-4999$ & 19 & 8.02 & 43 & 18.14 & 21 & 8.86 & 83 & 35.02 \\
$5000-7999$ & 6 & 2.53 & 12 & $\mathbf{5 . 0 6}$ & 8 & 3.38 & 26 & 10.97 \\
$8000+$ & 1 & 0.42 & 1 & 0.42 & 0 & 0 & 2 & 0.84 \\
TOTAL & 59 & 24.89 & 122 & 51.48 & 56 & 23.63 & 237 & 100
\end{tabular}

The following results emerge from Table 5:-

Socio-economic status

- The majority of the lower $(16.03 \%)$, middle $(18.99 \%)$ and upper $(16.46 \%)$ classes of consumers feel that price is sometimes a good indicator of quality.

- Just over half of the sample of consumers $(51.48 \%)$ feel that price is sometimes a good indicator of quality.

- If we combine the sometimes and never classifications, it can be concluded that the majority of consumers (75.11\%) are less likely to judge quality on the basis of price.

- In comparing the upper, middle and lower, classes, it is noted that whilst (10.55\%) of the upper class consumers see price as always being a good indicator of quality, an equal percentage of consumers $(7.17 \%)$ of lower and middle class individuals view price as a constantly good indicator of quality.

Gender

- The majority of the female consumers (31.65\%) feel that price is sometimes a good indicator of quality.

- The majority of the male subjects (19.83\%) are of the opinion that price is sometimes a good indicator of quality.

- More males feel that 'Price is always a good indicator of quality' (10.13\%) than 'Price is never a good indicator of quality' (7.59\%).

- More females believe that 'Price is never a good indicator of quality' (16.03\%) than 'Price is always a good indicator of quality' (14.77\%).

\section{Marital Status}

- The majority of the single (12.24\%), married $(36.29 \%)$ and divorced $(2.95 \%)$ consumers feel that price is sometimes a good indicator of quality.

- More single subjects feel that 'Price is always a good indicator of quality' (4.64\%) than 'Price is never a good indicator of quality' $(2.53 \%)$.

- More married consumers are of the opinion that 'Price is always a good indicator of quality' (19.41\%) than 'Price is never a good indicator of quality' (18.99\%).

- More divorced subjects hold the attitude that 'Price is never a good indicator of quality' $(2.11 \%)$ than 'Price is always a good indicator of quality' $(0.84 \%)$.

Education

- The majority of the consumers in each of the categories of education feel that 'Price is sometimes a good indicator of quality'.

- More subjects with a standard 10 level of education were of the opinion that 'Price is never a good indicator of quality' than 'Price is always a good indicator of quality'. However, more subjects in the other categories of education feel that 'Price is always a good indicator of quality' than 'Price is never a good indicator of quality'. 
Age

- The majority of subjects in all age categories are of the opinion that 'Price is sometimes a good indicator of quality'.

- More consumers below the age of 50 years maintain that 'Price is always a good indicator of quality' (21.94\%) than 'Price is never a good indicator of quality' (19.41\%).

- More subjects of and above the age of 50 years believe that 'Price is never a good indicator of quality' (4.22\%) than 'Price is always a good indicator of quality' $(2.95 \%)$.

\section{Income}

- The majority of consumers in each income category feel that price is sometimes a good indicator of quality.

According to Johnson \& Kellaris (1988), demographic factors may influence the strength of the price-quality relationship belief for certain consumer services.

\section{DISCUSSION}

\section{The evaluative criteria of price and quality}

The findings indicate that quality followed by price are considered to be very important general product criteria. However, when other product information is provided, the level of importance that consumers attach to these two product attributes diminishes. Peter \& Olson (1996) report on the effects of price on consumer affect, cognitions and behaviour and conclude that price is often used to determine quality when consumers are given no other information about the product. The finding suggests that when consumers engage in the purchase of grocery products other criteria, such as, freshness, nutritional value and shelf life supercedes the importance of quality per se. It must however, be noted that consumers view freshness, nutritional value and shelf life as elements of quality. Undoubtedly, an important implication for marketing, is the enhanced awareness of Indian consumers concerning health and diet.

In the study it was found that $77.6 \%$ of the consumers ranked quality as being the most important product criterion. This can be attributed to the consumers' desire to 'get their money's worth'. This implies that the consumer does not buy a product but the benefits that it offers. Furthermore, $65 \%$ of the households regarded price as being an important criterion when purchasing grocery products. The implication is that consumers develop personal forecasting rules for price since they anticipate prices, compare them to observed prices, and develop decision rules based upon the difference (Winer, 1986). The other 35\% of the consumers did not assign a rating of 5 (most important) to price. This can be attributed to the fact that highly committed consumers are less price sensitive than noncommitted consumers (Woodside and Fleck, 1979). Furthermore, when purchasing grocery products, consumers rated freshness, nutritional value, shelf life, quality and taste as being more important than price. Gardner (1983) concluded that the attributes an individual recalls or uses to evaluate a brand in a product class may vary.

Statistical tests of variance reflect no significant differences in the way in which consumers with varying biographical profiles (socio-economic status, gender, marital status, education, age, income) view the importance of price (Mean $=4.351)$. This confirms that hypothesis 1 may be rejected. Furthermore, socioeconomic status, marital status, education and gender do not influence consumer ratings of the importance of quality. However, ratings on the importance of quality differs across age groups and income categories respectively. Hence, hypothesis 2 may only be partially accepted (Table 3 ).

\section{Perceived price-quality relationship}

There are significant differences in the price-quality perception of Indian consumers in the Chatsworth area. The findings indicate that $24.89 \%$ of the subjects feel that price is always a good indicator of quality. These consumers' tendency to infer product quality from price reflects an implicit belief that there is a 1:1 relationship between price and quality, that is, they really get what they paid for. Hence, consumers who use price as an indicator of quality do so because they believe quality differences exist. Justifiably then, such consumers show greater preference for higher-priced brands than individuals who do not believe that quality varies among brands. Hence, marketers may successfully use the pricequality relationship to position their products as top-quality offering in their product category. Alba, Mela, Shimp \& Urbany (1999) deduced that brands may wish to be perceived as higher priced if they desire to position themselves in a premium category. Frequency analyses (Table 4) indicate that younger consumers and those in lower income categories are more likely to reflect the view that price is always a good indicator of quality. This finding is in keeping with research which indicates that when consumers have little confidence in their own ability to make the right choice (possibly due to lack of experience/youth) or experience doubt, they feel that the most expensive model is probably the best in terms of quality, that is, they equate price with quality (Schiffman \& Kanuk, 1991). More than half of the total sample (51.48\%) indicated that price is sometimes a good indicator of quality. This view is predominantly held by consumers with a higher level of education. If we combine the sometimes (51.48\%) and the always $(24.89 \%)$ categories, it can be deduced that the majority of the subjects $(76.37 \%)$ are more likely to base their judgement of quality on price. Similarly, Petroshius \& Monroe (1987, pp. 518 - 519) suggest that "price is used by consumers as an informational stimulus to form judgements about a product" and maintain that "price characteristics of a product line affects buyer's product evaluations". Rao \& Monroe (1989) also found that the relationship between price and perceived quality is positive and statistically significant. Furthermore, Mehta (1974) found that for clothing, price information does have a significant effect on quality perception. According to Hoyer \& Brown (1990), when consumers see price as a good indicator of quality and when quality differences exist among competing brands, they may 'pay a price' for employing simple choice heuristics such as brand awareness in the interest of economising time and effort. Furthermore, when consumers lack brand awareness, price is likely to be used when choosing a product (Hoyer \& Brown, 1990). This view is supported by Schiffman \& Kanuk (1991) who maintain that consumers use price as a surrogate indicator of quality if they have little other information to go on. However, Palliam (1988, p. 128) found that the majority of Zulu consumers $(65.11 \%)$ "suspend the judgement of the quality of a grocery product based on price".

However, evidence of the relationship between price and quality across product lines is conflicting. According to Johnson \& Kellaris (1988), the degree to which consumers believe in a price-quality relationship varies across service types. Gerstetner (1985) adds that, for many products, higher prices appear to be poor signals of higher quality. Data collected by Consumer Reports suggest that the prices that some manufacturers charge for certain kitchen appliances are unrelated to the products' quality (Schiffman \& Kanuk, 1991). A study of electrical and electronic products undertaken by Yamada \& Ackerman (1984) in the Japanese market supports this conclusion. However, Shugan (1983) argues that when marketers know that consumers use price as an indicator of quality, they are encouraged to raise the quality of their products. Brucks, Zeithaml \& Naylor (2000) found that consumers may use price to infer some aspects of quality more so than others, for example, price seems particularly important as a quality cue for the dimension of prestige but may seem less critical, or non-significant, for a dimension such as ease of use. According to Rao \& Monroe (1989), the strength of the 
price manipulation is shown to significantly influence the observed effect of price on perceived quality. Raghubir \& Corfman (1999) found that consistency with post promotional behaviour, distinctiveness in terms of how common it is to promote in an industry, and consumer expertise are important variables that moderate when price promotions have an unfavourable impact on brand evaluations. In this study, it was found that almost a quarter of the sample (23.63\%) feel that price is never a good indicator of quality. This opinion was again, expressed mainly by consumers with a higher level of education (matriculants and those with higher qualifications). Peter \& Olson (1996) believe that when consumers are given additional information about products (which is more consistent with marketplace circumstances), the price-quality relationship is diminished.

\section{CONCLUSION}

Evidently, marketers need to determine how consumers perceive quality rather than to focus solely on organisation-driven measures of quality. Although not easy to determine, it is clear that whilst some consumers use price as a surrogate of quality, others place less emphasis on the price-quality relationship. Only about a quarter of the subjects see price and quality as having a one to one relationship. Other consumers may use other criteria, for example, brand name, as a determinant of quality. Hence, quality may be viewed as a multi-dimensional concept which is composed of many components. Future researchers may therefore, analyse the impact of different dimensions of quality when analysing consumer judgement and choice of products and services, rather than to rely on overall evaluations of quality and its holistic relationship to price as a determinant thereof.

\section{REFERENCES}

Alba, J.W., Mela, C.F., Shimp, T.A. \& Urbany, J.E. (1999). The effect of discount frequency and depth on consumer price judgments. Journal of Consume Research, 26, 99-114.

Assael, H. (1987). Consumer behaviour and marketing action. Third Edition. Boston: Massachusetts: Kent Publishing Company.

Brassington, F. \& Pettitt, S. (1997). Principles of marketing. London: Pitman Publishing.

Brucks, M., Zeithaml, V.A. \& Naylor, G. (2000). Price and brand name as indicators of quality dimensions for consumer durables. Journal of the Academy of Marketing Science, 28 (3), 359-374.

Du Plessis, P.J., Rousseau, G.G. \& Blem, N.H. (1990). Consumer behaviour: A South African Perspective. Pretoria: Southern Book Publishers.

Engel, J.F., Blackwell, R.D. \& Miniard, P.W. (1986). Consumer behaviour. Third Edition. Hinsdale, Illinois: The Dryden Press.

Gardner, M.P. (1983) Advertising effects on attributes recalled and criteria used for brand evaluations. Journal of Consumer Research, 10 (3), 310-318.
Gerstetner, E. (1985). Do higher prices signal higher quality? Journal of Marketing Research, 22, 209-215.

Hoyer, W.D. \& Brown, S.P. (1990). Effects of brand awareness on choice for a common, repeat-purchase product. Journal of Consumer Research, 17 (2) 141-148.

Johnson, R.L. \& Kellaris, J.J. (1988). An exploratory study of price/perceived-quality relationships among consumer services. In Advances in Consumer Research, 15, 316 - 322.

Martins, M. \& Monroe, K.B. (1994). Perceived price fairness: A new look at an old construct. In Advances in Consumer Research, 21, $75-78$.

Mehta, S.C. (1974). Indian consumers: Studies and cases for marketing decisions. New Dehli: Tata McGraw-Hill Publishing Company Limited.

Obermiller, C. (1988). When do consumers infer quality from price? In Advances in Consumer Research, 15, 304-310.

Palliam, R. (1989). The significance to the marketing firm of brand loyalty to Zulu consumers in Natal. Bookbinding Services: Faculty of Economic Sciences, University of Port Elizabeth.

Peter, J.P. \& Olson, J.C. (1996). Consumer behaviour and marketing strategy. Fourth Edition. Chicago: IRWIN.

Peterson, R.A. \& Wilson, W.R. (1985). Perceived risk and price reliance schema as price perceived quality mediators. In J. Jacoby \& C. Jerry (Eds.). Perceived Quality, How Consumers View Stores and Merchandise. Lexington, M.A.: Lexington Books.

Petroshius, S.M. \& Monroe, K.B. (1987). Effect of product-line pricing characteristics on product evaluations. Journal of Consumer Research, 13 (4), 511-519.

Raghubir, P. \& Corfman, K. 1999. When do price promotions affect pretrial brand evaluations? Journal of Marketing Research, 36, 212-222.

Rao, A.R. \& Monroe, K.B. (1989). The effect of price, brand name, and store name on buyers' perceptions of product quality: An integrative review. Journal of Marketing Research, 26 (3), 35-357.

Venkataraman, V.K. (1981). The price-quality relationship in an experimental setting. Journal of Advertising Research, 21 (4), 49-52.

Schiffman, L.G. \& Kanuk, L.L. (1991). Consumer behaviour. Fourth Edition. Engelwood Cliffs, New Jersey: Prentice-Hall International, Inc.

Shugan, S.M. (1983). Price quality relationships. In T.C. Kinnear (Ed.). Advances in Consumer Research, 11, 627-632.

Wheatley, J.J., Chiu, J.S.Y. \& Goldman, A. (1981). Physical quality, price, and perceptions of product quality: Implications for retailers. Journal of Retailing, 57 (2), 100-116.

Wilkie, W.L. (1990). Consumer behaviour. New York: John Wiley and Sons.

Winer, R.S. (1986). A reference price model of brand choice for frequently purchased products. Journal of Consumer Research, 13 (3), 250-256.

Woodside, A.G. \& Fleck, R.A. (1979). The case approach to understanding brand choice. Journal of Advertising Research, 19 (2), 23-30.

Yamada, Y. \& Ackerman, N. (1984). Price-quality correlations in the Japanese Market. Journal of Consumer Affairs, 18, 251-265.

Zeithaml, V.A. (1988) Consumer perceptions of price, quality and value: A means-end model and synthesis of evidence. Journal of Marketing, 52, 2-22. 